Geneviève Du Pont-Thibodeau Jacques Lacroix

\section{Do cardiac children need more red blood cell transfusions than other critically ill children?}

Received: 12 August 2013

Accepted: 13 August 2013

Published online: 7 September 2013

(C) Springer-Verlag Berlin Heidelberg and ESICM 2013

This editorial refers to the article available at: doi:10.1007/s00134-013-3085-7.

G. Du Pont-Thibodeau · J. Lacroix $(\bowtie)$

Division of Pediatric Critical Care Medicine,

Department of Pediatrics, Sainte-Justine Hospital,

Université de Montréal, room 3431, 3175 Côte Sainte-Catherine,

Montréal (Quebec) H3T 1C5, Canada

e-mail: jacques_lacroix@ssss.gouv.qc.ca

Tel.: +1-514-3454931

Fax: +1-514-3457731

Anaemia is associated with a higher risk of mortality in cardiac adults [1,2] and children [3]. Only a red blood cell (RBC) transfusion can rapidly increase a low haemoglobin $(\mathrm{Hb})$ concentration. However, there is no such thing as a perfectly safe RBC transfusion: both transfusion-transmitted infections and non-infectious serious hazards of transfusion (NISHOT) can occur [4]. RBC transfusions are associated with a higher mortality rate in cardiac adults [5] and with more morbidity in cardiac children [6-9]. An association between RBC transfusions and worse outcomes does not mean that there is a cause-effect relationship; it means only that such a cause-effect relationship is possible, and it questions the assertion that RBC transfusions are actually more useful than harmful in patients with cardiovascular disease.

In clinical practice, cardiac patients receive more RBC transfusions than other critically ill children [9-11]. The question is what prompts physicians to prescribe an $\mathrm{RBC}$ transfusion. According to a self-administered survey, determinants in cardiac children include $\mathrm{Hb}$ level, patient's stability, active bleeding, inadequate $\mathrm{O}_{2}$ delivery (low $\mathrm{ScvO}_{2}$, high lactate level, low $\mathrm{SaO}_{2} / \mathrm{FiO}_{2}$ ratio) and low blood pressure [10]. However, the $\mathrm{Hb}$ level remains the most important determinant of RBC transfusion [10, 11]. Therefore, it makes sense to ask ourselves the following questions: in cardiac children, how much anaemia can we tolerate and when do the benefits of RBC transfusions overcome their harms?

$\mathrm{RBC}$ transfusions are given during the perioperative care of paediatric cardiac surgery in the operating room and in the intensive care unit (ICU). While cardiac surgery accounts for only $5 \%$ of anaesthesia episodes, it represents $58 \%$ of perioperative RBC use and $24 \%$ of total hospital RBC use [12]. The lowest $\mathrm{Hb}$ level below which an RBC transfusion must be given during a cardiopulmonary bypass (CPB) is not well characterised. Jonas et al. [13] reported that infants randomised at CPB onset to an haematocrit of $20 \%$ (Hb level: about $7 \mathrm{~g} / \mathrm{dl}$ ) had worse 1-year Bayley psychomotor development scores than those allocated to $30 \%(10 \mathrm{~g} / \mathrm{dl})$; this suggests that the $\mathrm{Hb}$ level should be maintained over 7 during a CPB, but it does not tell us what is the best and safest threshold $\mathrm{Hb}$ level for transfusion over $7 \mathrm{~g} / \mathrm{dl}$.

The uncertainty about the threshold $\mathrm{Hb}$ level with the best risk/benefits ratio also arises in the ICU after surgery. Most cardiac children (range: 46-79\%) receive at least one RBC transfusion during their ICU stay after a cardiac surgery $[15,16]$. However, recent data suggest that a restrictive transfusion strategy might be as safe, if not safer than a liberal transfusion strategy. A subgroup analysis that focussed on 125 cardiac children enrolled in the Transfusion Requirements in Pediatric ICU (TRIPI$\mathrm{CU}$ ) randomised clinical trial reported that a threshold $\mathrm{Hb}$ level of 7 was as safe as $9.5 \mathrm{~g} / \mathrm{dl}$ in stable non-cyanotic cardiac infants [14].

In this issue, de Gast-Bakker et al. [15] published a randomised clinical trial where they compared the 
outcomes of children allocated to receive an RBC transfusion if their $\mathrm{Hb}$ level dropped below $8 \mathrm{~g} / \mathrm{dl}$ (restrictive group) or below $10.8 \mathrm{~g} / \mathrm{dl}$ (liberal group) in the operating room and in the ICU. All children older than 6 weeks with a planned cardiac surgery were considered for inclusion; cyanotic cases were excluded. Patients were randomised before the surgery, and the research protocol on RBC transfusion was initiated in the operating room and maintained in the ICU up to discharge. One hundred patients were enrolled and retained for analysis. Risk Adjustment for Congenital Heart Surgery (RACHS) scores and the length of surgery, CPB and aortic clamp time were similar in both groups; PRISM III and PIM 2 were low. The $\mathrm{Hb}$ value before $\mathrm{RBC}$ transfusions and the lowest $\mathrm{Hb}$ level in the ICU were not reported, nor was the compliance with the research protocol. The total volume of RBC units given in the operating room and ICU was lower in the restrictive than in the liberal group $(186 \pm 70$ vs. $259 \pm 90 \mathrm{ml} /$ patient, $p<0.001)$. Duration of mechanical ventilation, length of ICU stay and incidence of adverse events were similar in both groups, but length of hospital stay was shorter in the restrictive group [median: 8 (IQR: 7-11) vs. 9 (7-14) in the liberal group, $p=0.047]$. Costs of RBC and plasma were 229 vs. 328 euros per patient. The authors concluded: "For patients with non-cyanotic congenital heart defect undergoing elective cardiac surgery, a restrictive RBC transfusion policy (threshold $\mathrm{Hb}: 8 \mathrm{~g} / \mathrm{dl}$ ) during the entire perioperative period is safe, leads to a shorter hospital stay and is less expensive".

There is no doubt that an RBC transfusion can be lifesaving in some patients. However, serious hazards of transfusion such as over transfusion, transfusion-associated circulatory overload (TACO), transfusion-related acute lung injury (TRALI) and transfusion-associated multiple organ dysfunction syndrome must be feared [4, $9,14]$. Data from different haemovigilance systems report that the overall complication rate of transfusion is up to four times higher in children than in adults $[4,16]$. On the other hand there is no evidence that the benefit of RBC transfusion is better in children than in adults. Moreover, there is no strong clinical evidence that cardiac children need more RBC transfusions than other critically ill children.

Clinicians must apply the "primum non nocere" principle to cardiac children. It must be recognised that the threshold $\mathrm{Hb}$ level below which there are more benefits than harms administrating an RBC transfusion is not well characterised during and after paediatric cardiac surgery. The study by de Gast-Bakker et al. [15] suggests that, in both the operating room and ICU, a threshold of $8 \mathrm{~g} / \mathrm{dl}$ is safe in infants with non-cyanotic cardiac disease if the RACHS score is $\leq 3$ and if their severity of illness is low; however, a large multicentre clinical trial is required before any strong recommendation can be made in this population. Moreover, it must be underlined that these data are not applicable to surgery with RACHS scores $>3$, to cardiac neonates and to children with cyanotic cardiac disease.

Conflicts of interest On behalf of all authors, the corresponding author states that there is no conflict of interest.

\section{References}

1. McKechnie RS, Smith D, Montoye C, Kline-Rogers E, O'Donnell MJ, DeFranco AC, Meengs WL, McNamara R, McGinnity JG, Patel K, Share D, Riba A, Khanal S, Moscucci M, Blue Cross Blue Shield of Michigan Cardiovascular Consortium (BMC2) (2004) Prognostic implication of anemia on in-hospital outcomes after percutaneous coronary intervention. Circulation 110:271-277

2. Sabatine MS, Morrow DA, Giugliano RP, Burton PB, Murphy SA, McCabe $\mathrm{CH}$, Gibson CM, Braunwald E (2005) Association of hemoglobin levels with clinical outcomes in acute coronary syndromes. Circulation 111:2042-2049

3. Kammache I, Parrinello G, Marini D, Bonnet D, Agnoletti G (2012) Anaemia is a predictor of early death or cardiac transplantation in children with idiopathic dilated cardiomyopathy. Cardiol Young 22:293-300
4. Taylor C, Cohen H, Mold D, Jones H, Davies T, Asher D, Cawley C, Chaffe B, Chapman C, Gray A, Knowles S, Milkins C, New H, Norfolk D, Still E, Tinegate $\mathrm{H}$, on behalf of the Serious Hazards of Transfusion (SHOT) Steering Committee (2009) The 2008 annual SHOT report. http://www.shotuk.org/shot-reports/

5. Wang D, Sun J, Solomon SB, Klein HG, Natanson C (2012) Transfusion of older stored blood and risk of death: a meta-analysis. Transfusion 52:1184-1195

6. Costello JM, Graham DA, Morrow DF, Morrow J, Potter-Bynoe G, Sandora TJ, Pigula FA, Laussen PC (2010) Risk factors for surgical site infection after cardiac surgery in children. Ann Thorac Surg 89:1833-1834
7. Pattakos G, Koch CG, Brizzio ME, Batizy LH, Sabik JF, Blackstone EH, Lauer MS (2012) Outcome of patients who refuse transfusion after cardiac surgery: a natural experiment with severe blood conservation. Arch Intern Med 172:1154-1160

8. Kneyber MCJ, Grotenhuis F, Berger RFM, Ebels TW, Burgerhof JGM, Albers MJJJ (2013) Transfusion on leukocyte-depleted red blood cells is independently associated with increased morbidity after pediatric cardiac surgery. Pediatr Crit Care Med 14:298-305

9. Demaret P, Tucci T, Ducruet T, Trottier H, Lacroix J (2013) Red blood cell transfusion in critically ill children. Transfusion 53 (in press)

10. Harrington K, Farrell C, Poirier N, Ducruet T, Lacroix J (2011) Survey on red-cell transfusion practices after paediatric cardiac surgery. Pediatr Crit Care Med 12:A82 
11. Bateman ST, Lacroix J, Boven K, Forbes P, Barton R, Thomas N, Jacobs B, Markovitz B, Goldstein B, Hanson J, Randolph AG, The Pediatric Acute Lung Injury and Sepsis Investigator's (PALISI) Network (2008) Anemia, blood loss and blood transfusion in North American children in the intensive care unit. Am J Respir Crit Care Med 178:26-33

12. Keung CY, Smith KR, Savoia HF, Davidson AJ (2009) An audit of transfusion of red blood cell units in pediatric anesthesia. Pediatr Anesth 19:320-328
13. Jonas RA, Wypij D, Roth SJ, Bellinger DC, Visconti KJ, du Plessis AJ, Goodkin H, Laussen PC, Farrell DM, Bartlett J, McGrath E, Rappaport LJ, Bacha EA, Forbess JM, del Nido PJ, Mayer JE, Newburger JW (2003) The influence of hemodilution on outcome after hypothermic cardiopulmonary bypass: results of a randomized trial in infants. J Thorac Cardiovasc Surg 126:1765-1774

14. Willems A, Harrington K, Lacroix J, Biarent D, Joffe A, Wensley D, Hébert P, Tucci M, The Canadian Critical Care Trials Group and the Pediatric Acute Lung Injury and Sepsis Investigators (PALISI) Network (2010) Comparison of two red-cell transfusion strategies after pediatric cardiac surgery. Crit Care Med 38:649-656
15. de Gast-Bakker DH, de Wilde RBP, Hazekamp MG, Sojak V, Zwaginga JJ, Wolterbeek R, de Jonge E, Gesink-van der Veer BJ (2013) Safety and effects of two red blood cell transfusion strategies in pediatric cardiac surgery patients; a randomized controlled trial. Intensive Care Med (in press)

16. Slonim AD, Joseph JG, Turenne WM, Sharangpani A, Luban NL (2008) Blood transfusions in children: a multiinstitutional analysis of practices and complications. Transfusion 48:73-80 